\title{
STEPPE FOODWAYS AND HISTORY ${ }^{1}$
}

\author{
Paul D. Buell
}

\begin{abstract}
Peoples of central Asia have long been a world apart with their own unique way of life and foodways. These have been based primarily upon carefully harboured dairy products, supplemented by occasional meat and whatever else could be obtained from the environment without limiting pastoralism. The paper describes these foodways and the changes that they have undergone over the centuries in response to contacts with the outside world, conquest, and empire. Focus is on the Mongols, whose world empire gave rise to a world cuisine, and Turkic groups such as the Kazakhs. The paper concludes that, due to globalisation and the destruction of traditional pastoralism, steppe foodways are now in rapid decline. The social base that has supported them for centuries has now been all but destroyed.
\end{abstract}

For nearly the last 3,000 years, almost all the Eurasian steppe was occupied by pastoral nomads. ${ }^{2}$ This vast region stretched from the borderlands of China and Manchuria well into eastern Europe, with varying extensions north and south. Generally the steppe was too cold or too dry for other uses so nomadism was the predominant way of life. Today, few pastoral nomads remain, and most are confined to remote, inaccessible areas, including Mongolia. The steppe itself is in decline, rapidly turning into desert. Even with the most careful use, vegetation is now too sparse in many areas to support livestock. Such changes are thanks to the coming of the railways, which, for the first time, made a full conquest from outside possible. New conditions allowed in a mass migration of sedentary farmers, along with the cultural patterns of the settled world. This includes

' I would like to thank Vivienne Lo for her warm support and encouragement, as always, in writing this paper, and Eugene N. Anderson, Priscilla Işin and Ngan Le for comments on earlier drafts.

${ }^{2}$ On the term and the varying extensions of the zone in question throughout history, see Lattimore 1962a, Lattimore 1962b, von Wissmann et al. 1956, Kremenetski 2003. 
sedentary conservation ethics, or rather, lack of them. Nonetheless, Eurasia's pastoral nomads have made their mark on history. During their heyday they were powerful players in international events. They forced not only their governments but even parts of their cultures on the sedentary world surrounding the steppe.

Below, I will look at one aspect of the interaction between the steppe and the sedentary world: the mutual influences of foods and foodways. The focus will be on the Mongols, who were the only people in history to unite China and Russia and points beyond under a single banner. The Mongols dominated Eurasia culture for nearly 200 years, from the early thirteenth until the mid-fourteenth centuries. Evidence for the influence of Mongol culinary traditions on the nonMongolian world is particularly clear and may even be traced down to the present day in the form of a few widely popular foods. Also examined will be the fate of today's surviving steppe pastoralists and how the decline of their traditional culinary traditions is symbolic of a larger assault on their cultures and even rights to exist as peoples. If present trends continue, they will disappear entirely in a few decades at most and their ways of life will be gone forever.

\section{Cultures}

The central Asian steppe has always been occupied by a great variety of peoples, sharing little more than a pastoral way of life. They were divided by language and in many areas of material and intellectual culture.

The first true steppe pastoral nomads known to history were the Cimmerians and Scythians. They are described in detail in the fifth century BCE by Herodotus in book four of his Histories. By his time, similar cultures had appeared throughout the Eurasian steppe, including in the borderlands of China. ${ }^{3}$ Most then spoke Indo-European languages. Other groups spoke languages no longer traceable today; among them the Xiongnu 匈奴, who became the dominant group in the eastern steppe after the third century BCE, and the European

3 The classic study of these early peoples on the China borderlands remains Prusek 1971. See now also di Cosmo 2002. 
Hun. ${ }^{4}$ Also present in the early steppe, no later than the first centuries $\mathrm{CE}$, were the ancestors of later Turks and even Mongols, speaking Altaic languages.

After the Scythians, and their eastern extensions, the Saka and $\mathrm{Hu}$ 胡, the first group to re-impose a common culture on the steppe were the Turks, the first fully literate steppe group. They dominated the steppe world from the sixth century until the rise of the Mongols. Turkic states still exist today in surrounding sedentary areas. ${ }^{5}$ They include, far to the south, modern Turkey, the most important. Turkicspeaking peoples also remain important cultural groups to the north in Turkistan, site of a number of other independent Turkic states.

The Mongols, appearing as conquerors in the thirteenth century, were the most powerful steppe group ever. Although increasingly Turkicised as time passed, except in East Asia where the main influences were from China, they strongly influenced all of the cultures they came into contact with. ${ }^{6}$ Today large numbers of Mongols are still found in Mongolia, China, and Russia. Those in China and Russia are increasingly assimilated to those countries' dominant cultures and in Mongolia they are threatened with assimilation too.

Eurasia today remains ethnically much as it was at the end of the Mongol period: Turkic-speakers are dominant in the west, Mongolian in the east. The major difference is that the pastoral-nomadism of the past is now long gone in most areas. The Mongols cluster about a bloated sedentary capital, Ulaanbaatar, whose population is now more than one million and still growing rapidly. Russians and other settlers long ago ploughed up the old Kazakh steppe as part of the Soviet Virgin Lands Campaign, and other similar nineteenth and early twentieth-century developments. Turkic Tatars are more likely today to work in factories and coalmines than herd sheep. Much the same is true of the Volga River Kalmyks, Mongolian-speakers living in an area known for its oil. Nonetheless, languages and older cultural patterns persist in most areas today, including foodways. All are now undergoing rapid change in response to globalization; in this case, a levelling of local cultures in favour of an international corporate and political reality.

${ }^{4}$ On the Xiongnu, see di Cosmo 2002.

${ }^{5}$ On the earliest Turks, see Scharlipp 1992; Esin 1980.

${ }_{6}$ On the Mongols of the Imperial era, see Buell 2003. 


\section{Steppe pastoral nomadism}

In the past, three key elements made the steppe way of life possible and, where the old ways persist, they still do. As the centrepiece of steppe life, culturally and economically, the horse makes both the mobility and extensive herding of the steppe nomad possible in the first place. When horses can be spared or were sacrificed, there is meat, and their milk can be fermented into kumiss. In a few drier areas, the camel has supplemented, but rarely supplanted, the horse. The camel gelding was, for example, the preferred mount of the Seljuq when they invaded Iran and Anatolia in the eleventh century. ${ }^{8}$ Today the Tuvinians ride the reindeer, but their culture is more Siberian than steppe. ${ }^{9}$

The herd animals that provide the livelihood of the nomad are the second key element. Among them, the most important is the sheep. Today's steppe sheep is relatively small. Its wool is of poor quality, adequate for felt-making, but not for weaving. To compensate, better quality sheep have now been introduced to the steppe to provide, at least, an export product. Little weaving has consequently been done on the steppe itself, other than card weaving among the Kazakhs, for example. ${ }^{10}$ The steppe sheep has primarily been bred, like the other herd animals of the steppe, to withstand fierce heat in summer and extreme cold in winter. It must live off very scanty natural pasture and be able to endure hunger and thirst.

Goats are less numerous, but no less important. They graze more aggressively than sheep, even climbing small trees and bushes in search of food. Their foraging can be harmful environmentally and destroy pastures but it is, nonetheless, a useful supplement to the less hardy sheep under particularly difficult conditions. Goats also provide a larger product than sheep, including highly useful goat hair and cashmere, of which the best varieties are exported.

Cattle have never been common on the steppe, in part because they require better quality pasture, and more water than sheep and

7 For what follows, see the discussion and literature cited in Buell et al. 2000, pp. 27-30 and passim.

${ }^{8}$ On the first Seljuq in Turkey, see Cahen 1968.

9 On the importance of reindeer riding, see Ingold 1980.

${ }^{10}$ Card weaving dispenses with the traditional floor or vertical, warp-weighted loom and uses instead perforated wooden or paper 'cards' through which yarn is passed to produce a woven ribbon which can be used to decorate ger or clothing. On traditional Kazakh society, see Tolybekov 1971. 
goats. When slaughtered, cattle provide far more meat than nomads can conveniently eat. Most steppe peoples also prefer the tastier dairy products of sheep and goat to those of cattle. Nonetheless, until relatively recently, cattle were particularly useful for drawing the carts upon which the nomads piled their tents and other material possessions. In Mongol imperial times, teams of oxen drew large palace tents. In fact, until the coming of motor vehicles, such teams were an essential part of nomadic mobility.

Also raised on the steppe are Bactrian camels, in areas cold and dry enough for them; they are sensitive animals unlike the dromedary that flourishes in hot deserts. Less common are yaks and sarlag, a Mongolian yak-cattle hybrid. Both are large and require special care, but are very hardy under Mongolian conditions. In Tibet at least, yak butter is highly prized to flavour tea.

The physical paraphernalia of nomadic life is the third element. It emerged over a very long period in response to the specific requirements of life on the steppe. One of its major components has been the nomadic ger incorrectly known in English as the yurt, a Russian borrowing from a Turkic word originally meaning 'people'." The ger is light and easily transportable, yet sturdy. Covered with layers of felt, it is warm and waterproof, especially when topped by a canvas cover, as most gers are today. They are still most Mongols' preferred residence. Today they even make up a large part of the housing of modern Ulaanbaatar, in its extensive 'ger district'. Also important are well adapted clothing, mainly of sheep skin or fur, for outside work, efficient harness of horses and cattle, and a great variety of specialised equipment and tools. One example is the lasso pole, or urga, used by the Mongols to catch horses without having to bring them to the ground.

The pastoralism practised by the nomadic peoples of the Eurasian steppe primarily involves a system of annual movement between lowlying winter pastures, and mountain summer pastures. There are many local variants. ${ }^{12}$ For example, some groups move along rivers, upstream in summer, downstream in winter; others, in desert areas, move in a circular pattern, without much change in altitude. Many other patterns are possible. Such movements are never at random

"The Kazakhs call it üi, 'house', or kiiz üi, 'felt house'; the Mongols ger.

12 On these variants in Mongolia, see Erdenebaatar 1996. See also Bat-Ochir 2001 . 
and are intended to prevent exhausting of local fodder resources by allowing herds to remain in one place too long. Movements also make the most of seasonal resources such as the rich stands of grass growing in the mountains during the brief summers there. These pastures, called khangay in Mongolian, are the environmental ideal of the culture, a true paradise, where much summer entertaining and relaxation goes on.

\section{Steppe foods}

Steppe foods have always come primarily from herd animals and anything else available during the annual treks, as long as the additional activities involved do not interfere with herding. Hunting has always been the most important of these, but the steppe groups have also gathered foods whenever possible. Herodotus provides one of our earliest notices of such activity. He suggests that bird cherries (Prunus padus), were a staple for at least one steppe group. ${ }^{13}$ In less

${ }^{13}$ See Herodoti Historiae, Book IV:23. Herodotus also records that many of the Scythian and other groups he discusses practised agriculture, growing not only grain such as millet, but onions, leeks, and lentils (IV:17), and describes their making of kumiss (IV:2), and the preference of early steppe groups for boiled food (IV:62). Many other accounts of early steppe peoples comment on their foods in passing. Ammianus, for example, records the following on the European Hun:

The people of the Hun, little noted in ancient records, dwelling [as they did] near the ice ocean beyond the Maeotic swamps, exceed all measure of ferocity. [They do so] to the degree that among them each cheek of their children is furrowed by iron from their very birth, so that when the timely vigor of hair comes forth, it should be blunted by the wrinkled scars; and so that they will grow old beardless, and without any grace, just like the eunuchs; all of them having compact and powerful members and fat necks, [all of them] unnaturally deformed and bent so that we might think them bipedal beasts, or like roughly shaped posts fashioned into images to furnish bridges with railings.

Nonetheless, having the shape of human beings, however unpleasant, they are so rough in their way of living that they have no need for fire, or for savory food, but eat the roots of wild plants, and the half-raw meat of whatever the herd beast, which [meat], inserted between the upper parts of the thighs and the backs of horses, they heat with brief warming. They are never roofed in any buildings, and they avoid them just like tombs set apart from common use. Nor can there be found among them a hut roofed with straw.

On the other hand, they are roamers, wandering through mountains and forests, and they become accustomed from the cradle to prefer frost, hunger, and thirst. While abroad, they never enter any roof (unless forced [to] by the greatest necessity), nor do they consider themselves safe when staying under a roof. They are covered by linen garments or [by garments] patched together from the skins of wild mammals; nor do they have one set of clothing for domestic use, and another for public use. Once they have inserted their necks 
settled times, food could also be obtained by raiding or trading. The food that flows into Mongolia today in exchange for gold and other Mongolian minerals is just a variation on traditional patterns.

Herd animals provide pastoralists' basic: milk, milk products, and, rarely, meat. During much of the year, herds are retained more or less intact, since animals are too valuable to slaughter. Instead, they are used primarily for breeding, extending lactation and producing more dairy products. Larger herds that result can be culled in late autumn and early winter for meat and to maintain optimum herd sizes for the difficult winter months, when herd losses can be quite severe. Winter losses have been particularly bad in Mongolia recently, although the weather alone has not been to blame. With Mongolia's current transition to a full market economy, at whatever the cost, the number of animals has grown too fast. ${ }^{14}$ The trick is to reach the spring with a herd that is just the right size, not too large for existing fodder resources, but still large enough to begin the cycle over again.

In any case, meat eating is not central to nomadic life. As a specific strategy to respond to changing conditions, dairy products available throughout much of the year, fresh or preserved, are the nomad's most important food sources, not meat. Excessive meat eating was, in fact, uncommon in most nomadic societies. It usually only appeared during extended contact situations, after the establishment of conquest states. This is in spite of early witnesses such as Ammiannus Marcellinus (circa 330-395), replete with beefsteak Tatar and other misunderstandings. ${ }^{15}$

into a tunic of ordinary color, it is not taken off or changed until, wasted by such long decay, it becomes rags.

They cover their heads with crooked caps, protecting their shaggy legs with [goat] kid hides, and their shoes are not prepared with any lasts and prevent walking in free steps. For this reason, they are little adapted to battles on foot, and are very nearly joined to their horses, strong but deformed, and sometimes sitting on these horses in the fashion of women, they perform their accustomed duties. Everyone in this nation buys and sells, night and day, from these horses. [Everyone] consumes food and drink [from these horses] and inclined over the narrow necks of their beasts of burden, they give themselves up to a most heavy, deep sleep, even including a richness of dreams. And when deliberation over serious things is proposed, all take counsel in common in that way. For they are led by no royal strictness, but are content with the hasty leadership of their pre-eminent persons, [and so led] they force their way through whatever they come upon (Rerum gestarum libri, book XXXI: 2:1-7).

14 See Buell and Le 2006.

15 See note 12. To my knowledge, Ammiannus is the first to notice beefsteak Tatar. Why the Huns or any other steppe people would have treated fresh meat, as opposed to dried meat, the true campaign rations of the time, in this fashion is 
In the steppe world, dairy products are consumed in various forms; almost all involving some form of fermentation. ${ }^{16}$ That has usually been put down to lactose intolerance, but it might be simply practicality and taste preference. Consumption primarily of fermented dairy products has been so widely and so long the practice that it has come to be considered a characteristic of the steppe world by sedentary societies. Some have even borrowed some of their terminology for fermented milk products from the steppe. For example, the common English word yogurt is a loan word from Turkish, through Bulgarian. Yogurts are widely eaten in various forms in the steppe world. ${ }^{17}$ They include yogurt dried for preservation (modern Turkish kurut). Steppe yogurt is usually made from sheep and goat's milk, but cow's milk is used when available. In contrast, mare's and camel's milk is reserved for kumiss, the prestige food of the steppe world. ${ }^{18}$ Its availability in abundance for an individual or group is an important sign of social status. Unfortunately, few nomads can own enough mares to ensure an adequate supply. Mares do not lactate continuously even when stimulated. So a large herd is necessary to supply even one person with a steady supply of kumiss. ${ }^{19}$ Usually, only the rich enjoy kumiss in abundance, although even the poor usually receive some - the sharing of food has always been a custom on the steppe. Sharing food is as important to a person's status and prestige as possessing it. ${ }^{20}$

Kumiss is usually only available in summer, when mares have mostly weaned their foals and there is a surplus of mare's milk. Kumiss is alcoholic enough to intoxicate, but its availability limited to only one season of the year discourages alcoholism from that source alone. The Mongols ferment kumiss in a large sack hung near the door of the ger. Anyone entering is supposed to punch the sack, or shake it to keep the fermentation going. Fresh kumiss is usually milky but can be clarified by further processing, resulting in

unclear, but one popular interpretation is that the fresh meat was intended as a medicinal for the horse.

${ }_{16}$ For an introduction to Mongolian fermented foods, see Indra 2003.

17 For a survey of traditional Mongolian foodways, see Damrinbazar 1991, and for Kazakh, see now Qatran 2003. See also Tsevel 1959.

${ }_{18}$ As an introduction, see Kumys Shubat 1979. Kumiss is from the Turkic word for this product, qymys in Kazah. It is ayrag in Mongolian.

19 Zhao Hong says that one mare can supply kumiss to three people. This figure seems high and probably only refers to a lactating mare after her foal has been weaned. See the Mengda beilu, p. 447.

${ }^{20}$ For an example, see note 26, describing early Mongolian Gastfreundschaft. 
'black', or clear kumiss (qarakumiss). ${ }^{21}$ This process concentrates the alcohol slightly, as the particulates are removed, but it is by no means distilling. This is a common misconception. Kumiss can be made from cow's milk, but its taste has never been popular.

When available, meat is usually eaten fresh, from a recently slaughtered animal, but it can also be dried for preservation. The Mongol imperial army, for example, took special campaign rations (Middle Mongolian š'usu) of dried meat. By tradition, hallowed by the word of Cinggis-qan (r. 1206-1227), every part of a slaughtered animal had to be consumed-except for the inedible parts such as the wool or hooves. ${ }^{22}$ After the excrement had been pressed out by hand, the intestines, too, had to be used. In fact, sausage made from intestine stuffed with blood and fat remains highly regarded in the steppe world. ${ }^{23}$

Boiling was the preferred form of cooking - it captured the essence or soul of the animal whose meat was being consumed. Boiling also helped to extend limited meat resources and provided valuable liquid in the dry steppe environment. ${ }^{24}$ Meat could also be roasted. The popularity of the practice varied strongly between nomadic groups and depended upon tastes and the meat available. In Mongol China, for example, the imperial dietary Minshan zhengyao 飲膳正要, 'Proper and Essential Things for the Emperor's Food and Drink', had many boiled meat dishes, but none for roasted meat per $s e^{25}$

${ }^{21}$ A classic description of the making of 'black' kumiss or qarakumiss is found in William of Rubruck. Note that the word, even though used in clear reference to Mongols, is Turkic, not Mongolian, showing the pervasive influence of Turkic culture on the Mongols even at that early date. See Sinica Franciscana, p. 178. Note Rubruck's indication that this is very much elite food.

${ }^{22}$ See the tradition in John of Plano Carpini, in Beazley (ed.) 1967, p. 57. One recipe for an exotic animal and perhaps unexpected food in the Yinshan zhengyao is for 'mountain oysters', certainly not a preferred Chinese delicacy:

jasa'a [Mongolian: 'testicles']

Two: unload and make into compact knots. Salt and work ingredients together with a dash of asafetida (about $3 \mathrm{~g}$.) and a quantity of onions (about $30 \mathrm{~g}$.). Scald quickly in vegetable oil. When done, add a quantity of saffron (about $6 \mathrm{~g}$.) dissolved in water. Add spices [not defined]. Sprinkle with finely ground coriander (Buell et al. 2000, p. 310).

${ }^{23}$ Examples of sausage recipes from the Yinshan zhengyao are those for Horse Stomach Plate (Buell et al. 2000, p. 310) and for Drum Qazi (Buell et al. 2000, p. 305). Both are somewhat assimilated with Chinese touches.

${ }^{24}$ See the discussion in Buell et al. 2000, p. 43. On the idea of the soul of an animal resident in the bone or marrow, see Roux 1984, pp. 160ff.

${ }^{25}$ For a complete translation, see Buell et al. 2000. 
Kebabs are absent from the early sources and appear to have gained popularity later. Like their name they are probably of Iranian origin.

As well as providing meat, slaughtered animals are also important sources of cooking fat. That is particularly true of the fat-tailed sheep whose tail and rump fats have become staples in many areas, and is added to enrich sausages. Fat and blood are essential ingredients to produce the high calorie food cold nomads need while working their herds. Fat is rendered into oil, but frying is uncommon among steppe peoples - quite the opposite of China.

Some parts of a slaughtered animal were reserved for special personages at a meal or feast. Among the Kazakhs, for example, a senior person might receive the eyes. ${ }^{26}$ By tradition, part of the animal has to be given to a neighbouring family or even to a passerby. This custom is even mentioned in the Secret History of the Mongols. ${ }^{27}$ Among the recent Kazakhs, the powerful used to take advantage of the tradition to eat free at the expense of their better-off retainers, a kind of food tax..$^{28}$ In any case, as in most societies, relatively complex rules govern food and eating among steppe societies.

The Secret History of the Mongols makes it clear that gathered plant foods were an important supplementary food source, as they were for almost all steppe groups. It tells how the mother of Temüjin, the later Cinggis-qan, nourished her abandoned family with a variety of despised foods, or so the Mongol chronicle would have us believe. They included wild apples, bird cherries, burnet root, cinquefoil root, scarlet lily bulbs, wild garlic, wild onions, and garlic chives, as well as two kinds of fish. ${ }^{29}$ Despite the prejudices of the Secret History, written to glorify the then ruling house of the Mongols, there is every evidence that such foods were very important on the steppe. Some groups of Mongols even specialised in fishing. ${ }^{30}$ One recent

${ }^{26}$ On Kazakh food customs, see Qatran 2002.

27 The passage reads:

After that, when Dobun-mergen one day went to hunt on Toqocaq Rise, he encountered Uriangqadai people in the forest. They had killed a three-yearold deer and were cooking its ribs and intestines. When Dobun-mergen spoke he said: 'Please give me [some meat] as the share of meat due another [nökör sirolqa ke'ejü'ü]'. Taking [only] half a breast side of the meat with the lungs, and the hide, they gave all [the rest of the] three-year-old deer's meat to Dobun-mergen (Buell et al. 2000, pp. 31-2).

${ }^{28}$ See Tolybekov 1971 , p. 124.

${ }^{29}$ See Buell et al. 2000, pp. 37-8.

30 See the Xiyu ji, p. 263. For a detailed discussion of fishing and other aspects of the Mongol economy of the imperial age, see Iwamura 1968, pp. 29-93. 
study suggests that fish were important almost to the exclusion of other foods among early inhabitants of the steppe zone. ${ }^{31}$ Modern Mongols know and regularly use scores of wild cereals, fruits and berries, mushrooms, bulbs, nuts, tubers, roots and greens. ${ }^{32}$

Wild game was another important supplementary food source for the Mongols. Thanks to Marco Polo and other early writers, we have a long list of the game taken: deer, wild boar, wild sheep, antelopes, wolves, foxes, hares, marmots, and even rats and mice. ${ }^{33}$ This does not include many varieties of fowl, mentioned in general terms by Marco Polo, and referred to more specifically in the imperial dietary manual, Yinshan zhengyao. Figure 1, for example, drawn from that text, shows two Mongolian game fowl, the Yeke Siraqun Qun, 'Golden-headed Swan', or Whooper Swan, Cygnus cygnus, and (below) the Qaralaq Qun, 'Lesser Golden-head Swan', the Tundra Swan, Cygnus columbianus. Swan meat, here evaluated in terms of traditional Chinese medicinal categories, is described as sweetish in flavour, heating and lacking strong medicinal effect. It is good for 'supplementing the centre and augmenting $q i$ 氣'. ${ }^{34}$

${ }^{31}$ See, for example, O'Connell et al. 2003.

32 See the discussion in Buell et al. 2000, pp. 38-42. See also Rinchen 1979. Damrinbazar (1991, pp. 149ff) lists wild leeks, a variety of onions, nettles, Cynanchum, Chinese yams, lily bulbs and seeds, Cenopodium, Sonchus brachyotus, the persimmon, Peteridium, Hemerocallis minor, Senecio campestris, mushrooms, Suaeda spp., dock, Imperata cylindrica, wild Chinese flower pepper, ephedra, wild cabbage, wild celery, Cistanche deserticola, Rheum Franzenbachii, Puguionium cornutum, Ulmus pumilla, Agriphyllus arenatirum, apples, mulberry fruits, red currants, hawthorn fruits, gooseberries, pears, bird cherries, acorns, chestnuts, apricots, pinenuts, wild grapes, wild jujubes, elm fruits, wild rose hips, walnuts, fruit of Hippophae rhaminoides, Nitaria fruits, Securinega suffruticosa fruits, and oleaster or 'Russian olive' fruits. The last are even featured in a Yinshan zhengyao recipe:

Russian Olive Fruit Soup

It supplements the center, and increases $q i$. It strengthens spleen and stomach. Mutton (leg; bone and cut up), tsaoko [Amomum tsaoko and other large cardamoms] cardamoms (five), chickpeas (half a sheng 升 [today about 31.5 cubic inches]; remove the skins).

Boil ingredients together into a soup. Strain [broth]. Add together to the pot: a cooked dried sheep's thorax (sliced up), 3 sheng of Russian olive fruits, Chinese cabbage or nettle leaf. Even and adjust flavors with salt (Buell et al. 2000, pp. 381-2).

${ }^{33}$ Damrinbazar mentions, for today's Inner Mongolia: deer, reindeer, elk, antelopes, wild sheep, wild and mountain goats, wild camels, kulan and other wild asses, the wolf, the lynx, the snow leopard, the leopard, the bear, wild swine, hares, tarbaqan marmots, badgers, bustards, geese, snipe, the lammergeyer, pheasants, quail, partridge, cranes, duck, and swans (Damrinbazar 1991, pp. 120ff).

${ }^{34}$ See Buell et al. 2000, pp. 468-9, 548. 


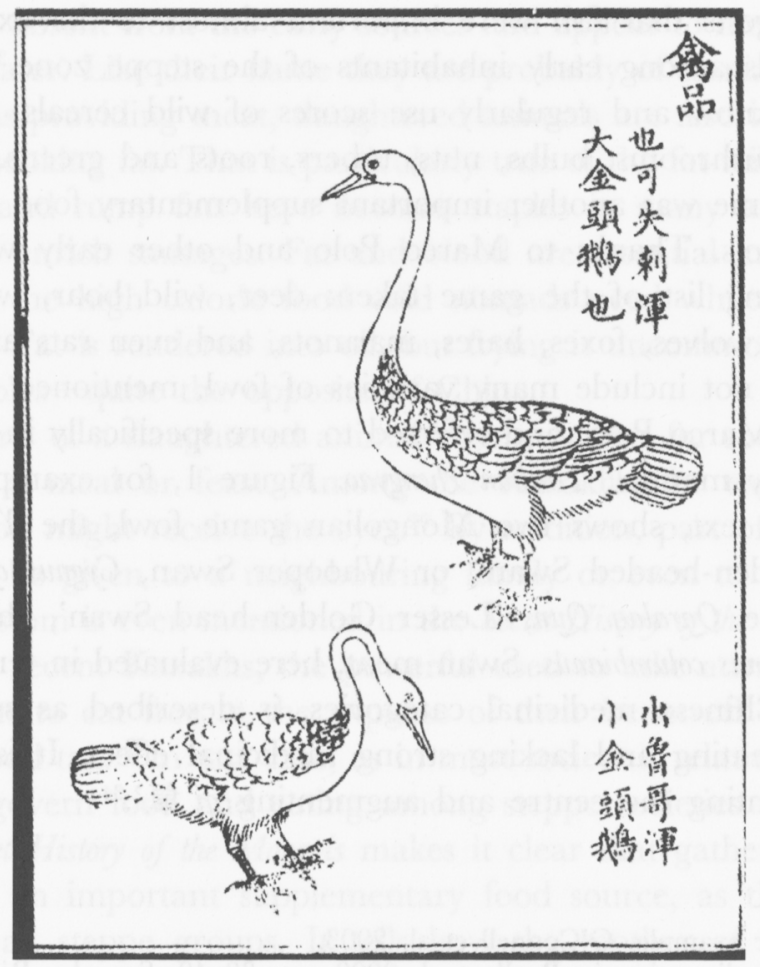

Fig. 1. Mongolian Hunting Fowl (Swans)

Figure 2, from that same source, illustrates the tarbaqan marmot, an abundant and even more important Mongolian game animal.

In our day, most animals are taken individually, but in early times, the Mongols organised great battue hunts, which confined the animals into ever smaller areas, where the powerful were awarded first shots. Some animals were allowed to escape to maintain stocks for future hunts. ${ }^{35}$ The hunts provided large numbers of animals for consumption and excellent military training. The techniques involved were widely used in hunting human enemies.

All animals are sacred to the spirits of the Mongolian land and waters, another reason for the releasing of animals during the battue hunts, lest greedy humans offend the spirits. It is no accident that qoryq, the modern Kazakh word for a nature reserve, originally meant a sacred area, where hunting of any animal was forbidden out of

${ }^{35}$ See the classic description in The History of the World Conqueror by 'Ala-ad-din 'Ata-Malik Juvaini, I, pp. 27-8. 


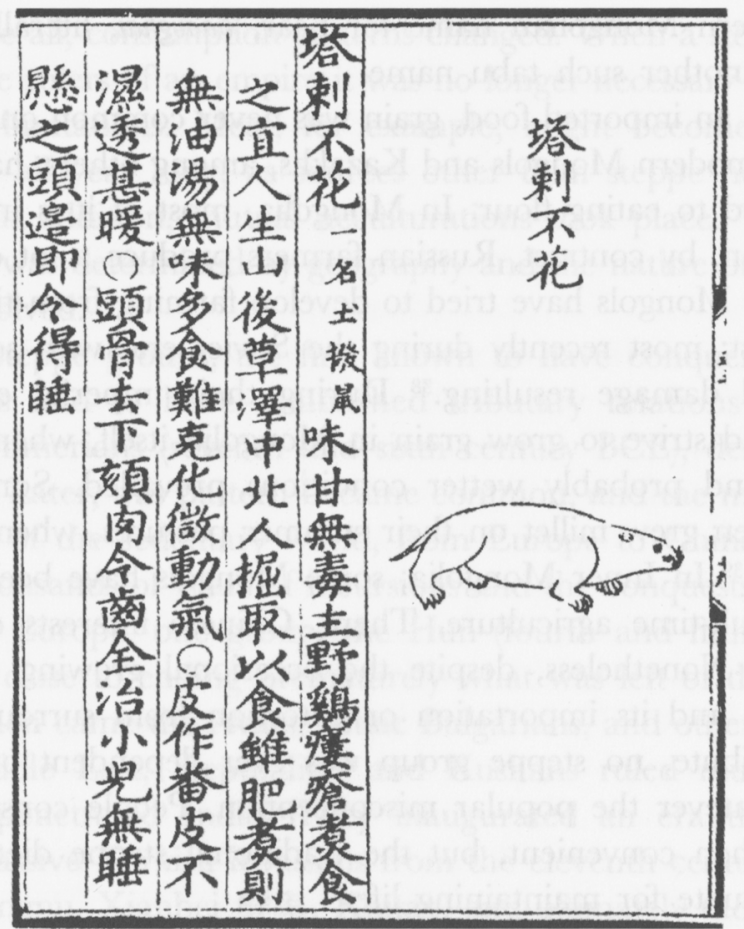

Fig. 2. The Tarbaqan Marmot

respect for the deceased. ${ }^{36}$ As they were sacral, animals were attributed special powers, including medicinal. The early Mongols made a conspicuous display of eating exotic animals. Mongolian ideas have been reinforced by Chinese, at least in Mongol China, although Chinese conceptions of powerful or strange animals having lots of $q i$, to be tapped into, was completely alien to the Mongols.

Animals with especially sacral character, such as the wolf, one of the ancestors of the Mongols, had to be killed in a special manner. Recent Kazakhs, for example, try not to shed the wolf's blood when hunting it; rather they use a rope, attached to the saddle of a moving horse, so that the animal breaks its own neck trying to escape. ${ }^{37}$ Associated with the sacral character of many animals is an elaborate system of tabu names. In Mongolian, the wolf, for example, is rarely called chono, 'wolf', but more commonly bori, 'the grey one'.

${ }^{36}$ As an introduction to the sacred biology of the Altaic peoples, see Roux 1966.

${ }^{37}$ I am grateful to Rakhmanqul Berdibayev for sharing this information with me (personal communication to the author, August 1991). 
The Modern Mongolian name for bear, baavghai, literally 'ancestor bear', is another such tabu name.

Even as an imported food, grain was never common on the steppe, although modern Mongols and Kazakhs, among others, have become accustomed to eating flour. In Mongolia, most of it is imported. In Kazakhstan, by contrast, Russian farmers produce a lot of grain for flour. The Mongols have tried to develop farming from time to time in the past; most recently during the Soviet era, with serious environmental damage resulting. ${ }^{38}$ During their imperial era, captive farmers did strive to grow grain in Mongolia itself, when somewhat warmer and probably wetter conditions prevailed. Some Mongol groups even grew millet on their summer pastures, when conditions permitted. ${ }^{39}$ In Inner Mongolia, some Mongols have been forced to take up full-time agriculture. There, Chinese interests continue to dominate. Nonetheless, despite the occasional growing of grain in Mongolia, and its importation or extortion from surrounding peoples as tribute, no steppe group was ever dependent on imported grain, whatever the popular misconception. People consumed it by choice, when convenient, but the traditional steppe diet was more than adequate for maintaining life.

\section{Contact situations and food}

For much of the past history of the steppe world, life there was rarely purely traditional. Many steppe peoples could impose forced relationships on the sedentary world thanks to their superior military power. But the coming of mobile gunpowder weapons, and of huge sedentary states with enormous power, dwarfing the small tribal levies of the steppe world, changed everything. The nomads' worlds have been reversed since the eighteenth century, when Chinese and Russians subdued the Dzungars and Kazakhs respectively, the last steppe powers to seriously threaten the sedentary world. ${ }^{40}$

Extended contact with the outside world, especially the sedentary domains lying beyond the steppe, brought changes in food and food-

\footnotetext{
${ }^{38}$ See the discussion in Buell and Le 2006.

39 On Mongol growing of millet, see the Mengda beilu, p. 447. On Chinqai and his city of captive farmers, see Buell 1994.

40 See now the full discussion in Perdue 2005.
} 
ways. Above all, consumption patterns changed. When a steppe group had become rulers of an empire it was no longer necessary to observe traditional limitations. Meat, for example, might become available in quantity all year long, as sources other than steppe herds could supply it. In addition, mutual acculturations took place. Their precise nature was determined by geography and the nature of the interactions involved.

Among steppe groups, the first known to have conquered sedentary groups and to have established tributary relations were the ancient Kimmerians (seventh and sixth century BCE), described by Herodotus. Later, this pattern became common, and the more developed areas of the sedentary world, from Europe to China, suffered not only thousands of years of incursions and the conquests of steppe peoples. In Europe, one group, the Hun (fourth and fifth centuries $\mathrm{CE}$ ), came close to ending prematurely what was left of the Roman Empire. Then came the Avars, Altaic Bulgarians, and other invaders. In the Middle East, Hepthalites and Kushans ruled much of the area, and penetrated India. They inaugurated an era that culminated in massive Turkish invasions from the eleventh century. China had its Xiongnu, Xianbei 鮮卑, Khitan, and ultimately the Mongols, the first steppe people to conquer all of China. The Mongols also invaded Europe, controlled Russia for centuries, and established states in Turkistan and Iran. A renewed era of Turkish invasions and control followed that of the Mongols, until a new Mongol group, the Dzungars, terrorised the sedentary world.

A continuum of steppe foods developed. They ranged from the traditional to the assimilated. The common steppe nomads, without access to many of the foods regularly eaten by the more powerful, conquest elites, ate the most traditional diets. Those elites were usually present in conquered sedentary domains, with which they increasingly identified. Even so, common nomads, in the Mongol Empire, for one example, had access to some foods considered exotic by steppe traditions. The contrast between a traditional and a conquest sector cannot always be clearly drawn. Pastoral nomads, including former Siberian peoples, who were relatively recent converts to that way of life, retained some foods by no means traditional to the steppe.

One of the major changes taking place as steppe groups interacted with the sedentary world was an increase in the use of grain and grain-based foods. During the Middle Ages and early modern times, this included distilled liquors fermented from grains as the 
technology spread. ${ }^{41}$ That process is well-documented for the Turks by the 1073 Dictionary of the Turkic Dialects (Dīwān Lughät al-Turk) of Mahmūd al-Kāshgarī, which has entries relating to more traditional Turkish foods as well. ${ }^{42}$ Mahmūd was anxious to record Turkic vocabulary from all sources, including the more traditional, but his most important sources were those Turkic groups most familiar to him in his native eastern Turkistan. Many of these groups had, by his time, become semi-sedentary or entirely sedentary in connection with their rule over the oasis states of their area.

Time-honoured favourites noticed by Mahmūd include: yogurt; ${ }^{43}$ ayran, ${ }^{44}$ a watered down yogurt for drinking; et, meat; and kakuk, ${ }^{45}$ dried meat. Among the assimilated foods are a surprisingly large variety of grain and bread foods. They range from porridges and gruels, simple ashcake, to fried batter cakes, and bread, in the strictest sense, both flat and loaf breads. ${ }^{46}$ One of them, čuqmin, is steamed in a special pot. ${ }^{47}$ There is also layered bread, and a pie, called böräk, the grandfather of the great variety of foods called 'borek' today. ${ }^{48}$

${ }^{41}$ On the history of distillation, see, as an introduction, Huang 2000. See also Needham et al. 1980. The fujia biyong shilei, reflecting usage during the middle of the fourteenth century, includes the following recipe for a distilled liquor:

\section{'Cooked' Liquor}

Whenever one cooks liquor, use 2 qian [Chinese ounces] of wax, 5 slices of bamboo leave, and 'official' Arisaema japonica, a good half-a-tuber for each dou [Chinese peck]. Transform [i.e. process] and put into the liquor. Close up tightly according to method. Place inside a boiler. ([subtext] During autumn and winter use an Arisaema japonica 'pill'. During spring and summer use wax and bamboo leaves). After that start the fire. Wait until the aroma of the liquor penetrates up into the boiler twists. The liquor will come forth in profusion. Then raise the boiler again. Then take up the entire pot [with the liquor], open up and look. If the liquor is boiling then it is ready. Put into the fire for a long time. When you take it down put into lime. One should not move continuously. One wants the white liquor to expel to obtain the clear liquor. Afterwards when cooking again and again, use mulberry leaves to reduce. This is to prevent the aroma $q i$ from being cut off (Jujia biyong shilei, 11.35a).

The Arisaema may fulfill the role of hops in this recipe, i.e. preventing the wrong kinds of fermentation, but this is unclear. For examples of fermented beverages in the Yinshan zhengyao, see Buell et al. 2000, pp. 525-9.

${ }^{42}$ For an introduction to food content of this important text, see Perry 2000.

${ }^{43}$ Algar 1991, pp. 3, 271f. The word occurs many times in the Diwān Lughāt al-Turk but a separate article seems to be lacking.

${ }^{44}$ Divanü Lûgat-it-Türk, vol. I, p. 120.

${ }^{45}$ Divanü Lûgat-it-Türk, vol. III, p. 130.

${ }^{46}$ See the summary in Perry 2000.

${ }^{47}$ Perry 2000. See the recipe for one version of such bread in Buell et al. 2000, p. 317.

${ }^{48}$ See Perry 2000. 
Mahmūd's Turks, judging by his entries also ate noodle soups and made a meat breading, which may be ancestral to the most ubiquitous of later steppe grain foods, the fried or steamed dumpling now known as manty. Unfortunately, the reading for this word is uncertain in Mahmūd's text and we cannot be sure. It could be yamata, tamata, or even mamata; the last reading would make the most sense. ${ }^{49}$ Exactly the same food appears to be described in the cookbook of the fourteenth- century Chinese scholar, Ni Zan (1301-1374) 倪瓚，as a breading for sparrow, called mantou 饅頭. This word is apparently a transcription of Turkic manty. ${ }^{50}$

Liquors fermented from grain appearing in Mạ̣mūd's dictionary include a number of beers. Among them is one called boza. ${ }^{51}$ Later the same term was applied to what is apparently distilled millet vodka. ${ }^{52}$ There is, as of yet, no evidence for distilled beverages among the eleventh-century Turks known to Mahmūd. This situation changed as distillation technology spread in central Asia-no later than the thirteenth century.

By Mahmūd's time, the Turkish sweet tooth, another assimilated taste, had already made its appearance, although steppe Turks certainly used honey. Mahmūd mentions, for example, pekmez, ${ }^{53}$ molasses made from various fruits. This was clearly a food of settled Turks. The fruits involved were extremely unlikely to be available on the steppe, or anywhere near it.

Maḥmūd's dictionary conjures a picture of an assimilating Turkish food culture and that is confirmed by other sources. The great mystic poet, Jalāl al-Dīn Rūmī (d. 1273), describes Turkish foodways that were even more assimilated, embracing a diet that was considerably richer in vegetables. They included leeks, celeriac, spinach, and turnips, along with onions and garlic, a traditional taste; as well as various legumes, including black-eyed peas and lentils. The latter was a major Middle Eastern staple. Tutmas, a prepared dish of the time, prominently mentioned by Rūmī, was a stuffed noodle eaten with yogurt that was all the rage of the Mongol world. By then this world included the states of Turkish Anatolia, which had been reduced

49 Ibid.

${ }^{50}$ See Wang and Anderson 1998, pp. 28-9. For a complete discussion of the derivation and history of the Chinese term, see Buell 1999, pp. 200-23.

${ }_{51}$ See the discussion in Perry 2000, pp. 633-4.

${ }_{52}$ Buell et al. 2000, p. 529.

53 Divanü Lûgat-it-Türk, vol. 1, pp. 440, 459. See also Algar 1991, p. 288. 
to tributary status early in the Mongol expansion. Rūmī also mentions a puree of mutton and wheat, which may be little more than a variant of another Mongol court food, to be described below, and a soup with small meat-filled dumplings, equivalent to soups eaten elsewhere in Eurasia during the Mongol era. ${ }^{54}$

The Mongol dishes Rūmī noticed were themselves products of a long period of cultural assimilation. Native Mongol foods had undergone changes similar to those experienced by native Turkic, in response to conquest, empire, and closer relations with the sedentary world. That meant access to a greater variety of raw foodstuffs, including quite exotic tribute products from much of the Old World. As conquerors, the Mongol elite could employ specialised cooks to create culinary delights with their tastes in mind. Change became particularly noticeable as the once unified Mongol Empire split into successor qanates, after 1260. A regionalisation of Mongolian imperial culture took place, but common Mongol traditions in food and foodways were noticeable to the end.

As had been the case with the Turks, one of the first indicators of Mongol culinary change was an upsurge in the use of grain foods and products, including apparently increased consumption of ashcakes and unleavened breads. The earlier accounts do not mention such foods, which come to light as the Mongol Empire was formalised. Even so august a personage as qan Möngke (r. 1251-1259) ate a primitive tsampa, ground millet or flour prepared with butter, or sour milk. The current practice of mixing with tea had not yet caught on..$^{55}$ Tea-drinking had yet to gain ground among the Mongols. Tsampa is often associated with Tibet, but it could have been invented anywhere.

Fermenting grain into liquor was just as important a use of grain as it was among the eleventh-century Turks. The Mongols drank beer made from rice and almost certainly from millet. Their other alcoholic beverages perhaps included distilled vodkas. ${ }^{56}$ By then, distillation was becoming as increasingly important in central Eurasia as it was in China.

${ }^{54}$ Algar 1991. pp. 6-7, 174. On the foods of Rūmī, see Schimmel 1978, pp. 138-48. See also, on early Turkish foods in general, the discussion in Arsel et al. 1996. For a tutmas recipe from the Yinshan zhengyao, see Buell et al. 2000. pp. 298-9.

${ }_{55}$ See the discussion in Buell et al. 2000, p. 48.

${ }^{56}$ See the liquors of the Yinshan zhengyao discussed in Buell et al. 2000, pp. 525-9. 
While eating new foods, the Mongols stayed true to their oldest foodways. William of Paris's famous fountain, in the form of a world tree, designed for Möngke's palace in Qara-qorum, produced alcoholic beverages to supply the guests at court. Its spouts gushed forth rice beer, kumiss and caracosmos (qara-kumiss), i.e. clarified kumiss, and a honey wine called boal, probably a traditional liquor, although the availability of honey in quantity may have been something new:

Mangu [Möngke] himself has a great court at Caracarum near the walls of the town. It is closed off by a brick wall, just as priories of monks [are closed off] among us. There is a large palace there in which Mangu holds his drinking parties twice a year: once around Easter when he passes by there; and once in the summer when he returns. And the second drinking party is the greater since on that occasion there convene at his court all the nobles from anywhere, as far away as two months' journey. And on that occasion he bestows attire and favors, and shows his great glory. There are there many other houses, long as barns, in which are stored his food provisions and treasures.

At the entrance of this great palace, because it would be unseemly to introduce skins with milk and other drinks, master William of Paris made for them a great silver tree, at the roots of which are four silver lions, each having a channel spurting out white mare's milk. And four pipes are led into the tree, leading up to the summit of the tree, and the tops of the pipes are bent back downwards, and over each of them is a gilded serpent, the tails of which envelop the trunk of the tree. And from one of these pipes pours forth wine; from another caracosmos, that is, clarified mare's milk; from another boal, that is, a honey drink; and from another rice beer, called terracina. And for each drink there has been prepared at the foot of the tree its own silver vessel for receiving the drink, between the four pipes. At the very top, Master William has made an angel holding a trumpet, and below in the tree he made a crypt in which a person can hide. And a channel ascends through the middle of the heart of that tree as far as the angel. At first Master William made a bellows, but it did not provide enough wind. Outside the place there is a room in which the drinks are stored, and there stand there officers ready to pour them whenever they hear the angel trumpeting. And the tree has silver branches and leaves and fruits.

Therefore, whenever there is need of drink, the master of the waiters calls to the angel to sound the trumpet. Whereupon, the one who is hidden in the crypt, hearing this, blows strongly into the channel leading to the angel and the angel puts the trumpet to its mouth, and the trumpet sounds extremely loudly. Whereupon, the officers in the room, hearing this, each of them pours out his drink into the appropriate channel, and the pipes pour them from above and below into the 
vessels prepared for that purpose, and thereupon the waiters draw them and bear them through the palace to the men and women. ${ }^{57}$

As late as the 1270s, Qubilai-qan (r. 1260-1295), then ruler of the Mongol successor state of qanate China, fed his captive Song Dynasty court a number of Mongol favourites, including leeks and onions (on an engraved platter), kumiss, mutton, horse meat, and camel's hump, bear, and other game meats. At least one culturally assimilated food, a stewed 'congee' made from grain was served. It was probably a mutton soup thickened with grain, almost certainly the type of dish known as harisa in Mesopotamia. The 'thick fluids' mentioned in addition may have been fruit liquors, part of the Arabic sharāb tradition, if we may judge by later usage..$^{58}$

As time went on, such acculturated foodways became more and more important. We are fortunate to have two important sources documenting court and general elite food usage in Mongol China of the fourteenth century. One is the Yinshan zhengyao mentioned above, a work by the dietary physician $\mathrm{Hu}$ Sihui 忽思惠 (flourished first half of the fourteenth century). He was possibly a Chinese Turkicspeaker, and presented this great compendium of his art, to the court in 1330.

It was written during a period of great Chinese influence upon the Mongols and their court. That is closely reflected in the cultural icons and values $\mathrm{Hu}$ chose. The Minshan zhengyao contains short biographies of the Yellow Emperor and other Chinese cultural heroes, and attempts to orient itself in accordance with the latest Chinese medical theories..$^{59}$ Nonetheless, the 213 court recipes at its kernel are strongly representative of central Asian and other non-Chinese traditions, from as far west as Baghdad. The foodways described are reflective of a larger Mongolian world order with cultural influences from various directions - not just China. Mongol tastes and choices still dominated the whole.

The second work is the fourteenth-century encyclopedia, Fujia biyong shilei 居家必用事類, 'Various Things for Use at Home', which includes a substantial recipe section. The foods are similar to those in the Yinshan zhengyao, showing significant central Eurasian, particularly, Islamic influences. The most important are the 12 'Muslim' recipes

\footnotetext{
57 William of Rubruck in Sinica Franciscana, pp. 276-7.

58 Shuiyun $\ddot{j}, 6: 7 \mathrm{~b}-8 \mathrm{a}$.

${ }^{59}$ See Buell et al. 2000, pp. 3ff.
} 
found in book 13 of the encyclopedia. ${ }^{60}$ The Turkic intermediation of most of them is readily apparent.

Of the 213 recipes in the Rinshan zhengyao, the most important are the 95 'Strange Delicacies of Combined Flavours' of book 1. Among them are 27 rich banquet soups (sülen), strongly reflective of the central Asian preference for liquid foods. Each is based on a mutton broth, flavoured with large cardamom (Amomum sp., not the familiar small cardamom of modern cooking) ${ }^{61}$ to which the cook would add one or more thickenings. Chickpeas, a Mesopotamian contribution to Mongol cuisine, were the most common thickening - they appear in 15 recipes. They are pulverised and skinned in the characteristic Mesopotamian manner. Other thickenings are fenugreek seeds - also from the Near East - oleaster fruits, a Mongolian gathered food, and barley. In six recipes, rice is used to thicken, in three in combination with chickpeas. ${ }^{62}$

The results vary considerably. Mongol banquet soups were not necessarily fluid. In seven of those 27 recipes, the ingredients are dry-cooked. A further seven yield thick, but still liquid, stews. One is for a spicy bread stuffing. Only 12 of the 27 are recognisably liquid 'soups'. Despite these variations in texture, all are more or less the same dish. Additives determine the differences in flavour. In 17 of the recipes, a cook would need vinegar. This use of vinegar probably represents Turkic influence. Other additives include onions, leeks or chives, ginger (probably a Chinese touch), sheep offal (a Mongol and Turkic favourite, ten times in all), a mysterious 'sheep's liver sauce' (five and possibly six times), and black pepper (nine times). Black pepper is a Middle Eastern spice and was rare in China. Clearly such dishes are much-improved versions of Mongol broths, as eaten from time immemorial on the steppe, with whatever was available added to thicken. ${ }^{63} \mathrm{~A}$ similar 'Mongolian' recipe, a sülen, chickpeas and all, is called for in a sixteenth-century Moghul court etiquette book; its origins in Mongol court cuisine were by then obvious to all. ${ }^{64}$ It may have been called 'Mongol', but the roots of this dish went back as far as ancient Mesopotamia, an area that leant a lot to Mongol court cookery.

\footnotetext{
${ }^{60}$ For a complete translation and general discussion, see Buell 1999.

(i) See the discussion in Buell et al. 2000, pp. 104-5.

${ }_{62}$ See Buell et al. 2000, pp. 104ff and passim.

${ }_{63}$ See the discussion in Buell et al. 2000, pp. 104ff.

it Perry 1985.
} 
Among the 95 are a complex of 23 that are either specifically noodle recipes, or call for noodles. Fifteen recipes describe stuffed noodles, and in nine they are fried..$^{65}$ Some have non-Chinese names such as tutum-ash, a dialectical variant of the tutmas of Rūmì and other contemporary cookbooks. Here the noodle (ash) is made with white flour, presumably using techniques similar to the flour coatings of modern Turkish cooking. The noodle is then stuffed with quruq qima, a well-roasted mutton, cut up finely. After stuffing, the tutumash was cooked in a 'good meat soup', the flavours 'adjusted' with onions, before being served with a sauce. The sauce was made from garlic, cream or, more probably, yogurt, and 'aromatic vegetable', either finely ground basil, or possibly mint, judging from modern Turkish practice. ${ }^{66}$ The result is actually quite tasty, and the Eurasian popularity of this dish, or its variants, is easy to understand.

The remaining 45 recipes of the group of 95 are more individual, and include a number of interesting soups. One of them is labelled Uighur, with an Uighur name. This means that it probably came from eastern Turkistan, although other Turkic cultures situated near China were also considered Uighur. It calls for sheep's tongues, mutton, and a northern mushroom under its Mongolian name, still used for it in China. ${ }^{67}$ There are many specialised wild game recipes, from goose to rabbit, and Eurasian curlew. ${ }^{68}$ This portion of the text incorporates some interesting breads, including several recipes for manty, which usually refers to a steamed dumpling. One of them, a variant of the standard manty, does not use a flour coating, the normal preparation method; instead, it is stuffed into the shell of an eggplant. This is still done in Uzbekistan, and in modern Turkey. ${ }^{69}$ There are also several boreks, generally termed 'horns', as in the fujia biyong shilei, with one variation, the recipe for päräk. This is a linguistic variant of modern Turkish börek from northern Eurasia and the Russian piroski. ${ }^{70}$

${ }^{65}$ Buell et al. 2000, p. 121.

${ }_{66}$ Buell et al. 2000, pp. 298-9. Compare the recipe in the Kitāb al-Tibākha. See Perry 2001.

${ }_{67}$ Buell et al. 2000, p. 300. The moog in question is Tricholoma mongolicum, and not any of the other species today passing under the borrowed name.

${ }_{68}^{6}$ Buell et al. 2000, pp. 308, 312, 304.

${ }^{69}$ Buell et al. 2000, pp. 313-14.

${ }^{70}$ Buell et al. 2000, p. 315. 
Perhaps the most interesting of the breads is a recipe for čuqmin, a steamed bread that we have already encountered among the Turks. In this version, ground Chinese flower pepper (Zanthoxylum spp.) and fennel are worked into the dough, and results in an extremely tasty treat, stuffed with stew. ${ }^{71}$ The Yinshan zhengyao also contains one of the earliest known recipes for poppy seed buns, not to be mistaken for the sweet rolls of the United States, since no sugar or honey is called for. The text mentions 'little black seeds', but the instruction to soak them in milk prior to use, makes it entirely clear that these are poppy seeds. ${ }^{72}$ Poppy seeds are also apparently most of the 'black' seeds of the Huihui yaofang 回回藥方, 'Muslim Medicinal Recipes', a manuscript fragment of an encyclopaedia of Islamic medicine almost certainly written under the Mongols. When the alternative black seeds, 'black cumin', Nigella sativa, are called for, the Persian name, shunīz, is used. ${ }^{73}$

Qurim Bonnets stands out among the recipes. Intended to be eaten during a Mongolian ritual feast, or qurim, it calls for some 20 ingredients, from mutton and sheep's tail, and sheep offal, to nuts, nut pastes, seeds, tubers, fruits, spices and other ingredients, including large numbers of eggs, which the Turks loved. All are combined and spiced, and then wrapped up in a bean paste skin (a Chinese touch), and finally steamed in cups with pine nut oil for flavouring. Despite the bean paste and a few of the ingredients, there is nothing Chinese at all about this dish. Its nearest equivalents were found far to the west where such display dishes were all the mode. Nonetheless, it is the Mongol taste for mutton and offal that determines the character of the dish. ${ }^{74}$

Elsewhere in the Yinshan zhengyao, one finds material that is more recognisably Chinese or purely Islamic, but even in such cases, there is strong evidence of a Mongol, or Turkic, sweet tooth. Chapter two of the dietary, for example, contains a repository of sweets, comprising around ten per cent of all the recipes in the book. There are sweet jams, jellies, along with purely Arabic concentrates such as julab and rubb, differing largely in their thickness. There are also sauce recipes, one of which seems to be for an Arabic khabis (hard

7 Buell et al. 2000, p. 317.

${ }^{72}$ Buell et al. 2000, pp. 316-17.

${ }^{73}$ Huihui yaofang, p. 28 and passim.

${ }^{74}$ Buell et al. 2000, p. 316. 
candy), fruit extracts, and syrups. One fruit extract is called a sharāb, the Arabic name for this type of delicacy. This section also has some interesting spiked punches, with their alcohol concentrated by freeze distillation-progressively spooning off the unfrozen slush of a ferment, resulting in a low-proof brandy. It also contains a number of sugar-bonded medicinals, all Middle Eastern in inspiration. ${ }^{75}$

The final chapter of the Yinshan zhengyao contains an extensive but uneven listing of the materia dietetica of the text, which omits many foods and spices used in the recipes, and adds others. This section is replete with non-Chinese influences, including a number of Mongolian game foods, some with their Mongolian names (see above), a few gathered plant foods, many of which also have Mongolian names, and many foodstuffs coming from Iran and other points west. This section also includes a number of distilled liquors, some under Arabic or Turkic names.

The Yinshan zhengyao contains many Mongolian words in Chinese transliteration in its text. Nonetheless, the preponderance of foreign vocabulary is specifically Turkic. ${ }^{76}$ This fact suggests strong Turkic intermediation and influences at work.

The same impression is made by recipes in the Fujia biyong shilei. Here are the twelve recipes from that text specifically called huihui 回回, a term usually translated as 'Muslim':

1) Chäkärli Piräk, 'sweet borek';

2) 'Rolled Thin Pancakes', fried dumplings with a rich filling, including a number of nuts, seeds, etc., and lamb;

3) Kogurma, or Turkic kavurma, a meat paste based upon sheep's head cooked to pieces;

4) 'Sour Soup', of uncertain provenance, based on black plums boiled in vinegar with sugar, with added nuts, and cream (or yogurt), and broth;

5) Tutum-ash;

6) Baldy, a honey (Turkic bal) dish thickened with paste fried in sesame oil and basted with butter;

7) Halwa, an Arabic sweet paste;

8) Güllach (Turkic, 'flower pastry'), a primitive baklava, although made with bean paste (flour) instead of durum;

9) Qoresh-e, a classic Persian stew;

${ }^{75}$ Buell et al. 2000, pp. 375-89.

${ }^{76}$ Buell et al. 2000, pp. 108-15. 
10) Julapia, Persian fritters made with bean paste again used in place of flour;

11) Qarisa (from Arabic harisa), a Persian meat paste made with mutton (or beef) and wheat and based with sheep's tail fat, or 'sheep's head oil';

12) 'West of the River Lungs', a recipe for sheep lungs Uighurstyle. ${ }^{77}$

The impression made by these supposedly common 'Muslim' recipes is thus specifically Turkic and Persian. None are even remotely Chinese, in spite of the bean flour or paste in two of the recipes. This is almost certainly an attempt to make up for the lack of good wheat (e.g. durum) flours in China. The cream or yogurt in recipe number four is a Turkic touch. The entire recipe would not be out of place in modern Turkic cooking from China.

The twelve 'Mulsim' recipes by no means exhaust the non-Chinese influences present in the Fujia biyong shilei. Many of the text's fried stuffed dumplings appear purely central Asian. Some are even explained using the Iranian term sambusak (sambusa)..$^{78}$ Foods of this sort had a long history in China, going back to the cosmopolitan Tang 唐 era (seventh to tenth centuries), but were not usually called for under a Persian name. (The twelve 'Muslim' recipes also call for a bread food under a Turkic name, kürshäk, one of the foods listed by Mahmūd al-Kāshgarīi). ${ }^{79}$ Several of the spice combinations are central Asian, but the Sinicisation of some elements is evident. ${ }^{80}$ Among the recipes

77 See Buell 1999.

78 Jujia biyong shilei, 14: 34a.

79 See the discussion in Buell 1999.

${ }^{80}$ Great Spice Combination for a Large (or Imperial) Kitchen:

Powder the following [quantities not given] and form into pellets with wet čumin:

Stinking Elm [processed pulp of Ulmus macrocarpa]

Less galangal [Alpinia officinarum]

Long pepper [Piper longum]

Greater galangal [Alpinia galanga]

Grains-of-paradise [Amomum villosum and $A$. xanthioides]

Chinese flower pepper

Dried ginger

Roasted cinnamon

[Ar.] Zhira [Dill]

Fennel

Mandarin orange peel [of Citrus reticulata]

Apricot kernel [of Prunus armeniaca]

Jujia biyong shilei, 14:40a. 
is one for bulghur wheat, a food rarely found east of Morocco, where it is a staple part of the diet. ${ }^{81}$

The cuisine of the Mongol empire as reflected in the rinshan zhengyao and the fujia biyong shilei became popular, not only in China, but throughout the Mongolian world. Two Mongol era foods that became staples throughout Eurasia were tutum-ash, or tutmas, and salma, 'water polished' noodles, which are probably the 'small soup noodles' noticed by Rūmī. Recipes for Tutum-ash (tutmaj) and salma are found in the fifteenth-century Iraqi cookbook Kitāa al-T ibākha. ${ }^{82}$ The most interesting of all Mongol era foods is baklava. The word seems to come from a Mongolian word, baqlakh, meaning 'to pile up in layers' ${ }^{83}$ Another cosmopolitan food promoted by the Mongols was borek, although it was certainly known to the Turks before the Mongols. Also popular and presumably spreading was manty. This word was already being used in Tang China for filled dumplings, and seems to have been known all across central Asia even then. It is now nearly universal in the Turkic world. Another food dating back possibly to the era of Mongol Empire is yuvqa, a filled bread with thin pastry covering. ${ }^{84}$ Whether the Mongols started the tradition of elaborate court recipes exemplified by the Yinshan zhengyao's 'Qurim Bonnets', we do not know, but such dishes certainly became far more popular throughout Eurasia during and after Mongol times, including under the Ottomans, who spread their own version of Mongol court cuisine far and wide.

Despite the rich tradition of assimilated Mongol court foods, and evidence for their spread throughout many parts of the Old World, the original foods of the steppe nomads persisted. This fact is clearly shown by the traveller Ibn Batțūta's accounts of the Turkic and other Central Asian foods of his time (early fourteenth century). He records that the Turks of his time did not regularly eat bread, and, like the early Mongols, preferred their food liquid rather than solid. In one dish, chopped meat was added to boiled millet and yogurt poured over the top - this was a common method of garnishing food during the period, as he makes clear elsewhere. ${ }^{85}$

${ }^{81}$ See the recipe (14: 40a) translated in Buell 1999.

${ }^{82}$ See Perry 2001.

${ }^{83}$ Discussion in Buell 1999.

${ }^{84}$ For an apparent recipe in the Yinshan zhengyao, see Buell et al. 2000, pp. 314-15.

${ }^{85}$ For an introduction to the foods involved, see Arsel et al. 1996. 
Dishes were also often eaten with milk. One of them is a dish he calls burkhani-a dried vegetable paste, cut up with a hole in each. It was cooked in a pot and served garnished with curdled milk. Horse and sheep meat was also eaten with milk, according to Ibn Batțutata and a noodle dish, the modern eriste, but perhaps with noodles not quite so fine as today's. This reference, of course, and the one to boiled millet indicate that assimilated foods were not unknown among the peoples visited by Ibn Batțutata, even though the boiling of millet in the steppe could be very ancient indeed. Ibn Bațtuța makes clear that bread was eaten on festive occasions, indicating non-Turkish influences on traditional Turkish foods. Likewise, the Turks of his time seem to have had access to various liquors, not only their native kumiss. One such liquor was a potent white beverage, drunk in small bowls. It was probably distilled from fermented millet. ${ }^{86}$ To this Ibn Bațtuța applies the name boza, also mentioned in the Yinshan zhengyao and earlier sources.

The foods of pastoral-nomadic Eurasia had probably assumed a classical form by the period immediately after the Mongol era, but new influences have swept over that world down to the present. One such influence was the coming of tea drinking, so enormous that one cannot imagine what Mongolian foodways were like before. Moreover, the Russians brought their varieties of vodka to the Mongolian and Turkic worlds. Distilled beverages were not unknown in central Eurasia, and some were probably quite similar to what the Russians introduced in far greater quantity. Vodka is today a major Mongolian import, and the Mongols even make their own, quite excellent variety, using wheat. Given what we know about the history of distillation, it may originally have come to Russia through central Asia and the Russians may have been taking coals to Newcastle.

The Ottoman Turks (fourteenth to twentieth centuries), unlike their ancestors, were no longer nomads, and their native foodways were transformed with the introduction of Persian and Balkan traditions to create one of the world's great cuisines. Ottoman food culture is still pervasive in the areas they once dominated, far beyond the boundaries of modern Turkey (including in Germany's Bosnian restaurants). This cuisine has been well described in a number of masterful cookbooks and studies. ${ }^{87}$

${ }^{86}$ Arsel et al. 1996.

87 As an introduction, see Alghar 1991, and Arsel et al. 1996. 
In India and Afghanistan, the latter already strongly exposed to central Eurasian foods and foodways, the coming of the Moghuls (who ruled in India from the sixteenth to nineteenth centuries) meant not only the imposition of a tradition of foreign rule that persisted for more than 300 years, but also a whole new set of foods. They were based in the rich Uzbek but heavily Persianised traditions of western Turkistan, and transformed upper-class Indian cooking. One of the dishes brought to India by the Moghuls was the Mongol banquet soup, as we know from the Moghul ceremonial book. ${ }^{88}$ Similar foods are still eaten in Pakistan and India today. They are in essence boiled mutton with flavourings and thickenings, sülen.

The first of the Moghuls to rule India was Babur (1483-1530), a Turk born in Kabul. He became ruler of an Uzbek state in Ferghana in 1494. From there, after some ups and downs, he had expanded his power over India by the time of his death. His diaries (Bäbur$n \bar{a} m a$ ) were originally written in Chagatay, the literary language of western Turkistan. They describe both the foods that he brought along from Uzbekistan, and the new food traditions he encountered as his empire expanded into India. Among the many traditional Turkic foods he mentioned are qaq (kakuk) (dried meat, already in Maḥmūd al-Kāshgar̄̄'s dictionary), horse, camel, and other 'fat' meats, and a sheep's stomach stuffed and made into a haggis (gipa). He also mentions semi-assimilated foods such as millet porridge, kebabs (known in much of Eurasia by Babur's time), and buttered fritters, already found in the Fujia biyong shilei. Despite these traditional or semitraditional elements, the foodways of south Asia and Iran are alive and well in his book. They embrace mango preserves, foods made from fine flours, cheeses (including a date palm cheese), sweet melons, grapes, fried and fresh carrots (an Ottoman favourite), lotus seeds, pistachios, wine, and medicinal confections $(m a j j u ̈ n) .{ }^{89}$ In the end, Babur, like conquerors before him, clearly had his feet in both worlds. Like others before him with their origins among the pastoral nomad peoples, he and his dynasty, considerably enriched their foodwaysand those of almost every culture they touched.

88 Perry 1985.

89. See the Bābur-nāma, pp. 148, 181, 394, 415, 421, 440, 493, 506, 508, 541, 542, 660 and passim. 


\section{Epilogue: Steppe region foods today}

Few pastoral nomads have been able to withstand the pressures of modern times. Nonetheless, older foodways persist in what was once the steppe zone. Kazakhs and Mongols, and other modern steppe groups, still prefer a diet based primarily on dairy products. The Mongols will still serve mutton soup, and everyone in the area loves greasy sausages. Grain foods, a legacy with a long past, are now widespread. The ubiquitous manty is virtually a universal food in Turkic central Asia. In Mongolia, more common is buuz, a steamed dumpling named after a Chinese bread, baozi 包子, that is as much central Asian as it is Chinese. But all of this may be temporary at best. Major changes now taking place will, if allowed to take their course, alter the foodways of nearly everyone in the region.

The coming of the global marketplace to even the most remote areas of the globe, including central Asia, is eroding communal institutions and communal ownership of pastures, vital for herding..$^{90}$ In their place, herds and pastures are to be privately owned with the old support network gone forever. The result in Mongolia, for example, is that while herding continues, it is less and less viable even when productive. The local infrastructure established during Mongolia's Soviet period to serve herdsmen and aid in marketing their products has broken down irretrievably. It has become difficult to market what products there are. Expanded herding around the capital, Ulaanbaatar, is no real solution. There is a limit to how many animals can live in an urban area without destroying it. Water resources are now much overused and highly sensitive with considerable competition for scarce supplies from new sectors of the economy, such as gold mining. Any increase of herding around Ulaanbaatar is likely to be short-lived.

These changes, coupled with the end of most Soviet-era experiments in local grain and vegetable production, mean Mongolia is faced with the challenge of maintaining its traditional diet. Most of the country's food has to be imported, and many of the imports are packaged foods. Currently Mongolia has a surplus of gold used to trade in the world economy. It depends upon two powerful neighbours, Russia and China, for most of its imports, including food. The political consequences of this may prove dreadful. And what

${ }^{90}$ See, as an introduction, Buell and Le 2006. 
today's Mongolians eat will be dependent upon the whims of the country's neighbours. Mongolia remains poor and imports from too far a field are out of the question - even paid for with gold, oil, and other mineral products. Thus, after thousands of years, the last pastoral nomadism is endangered, and the way of life associated with it is coming to an end. With it, the kinds of traditional foodways described here are threatened. Such changes are not confined to Mongolia. Kazakhstan, the largest central Asian country, and once almost entirely pastoralist, is now a mixed nation of Russians and Kazakhs (and others). Most of its inhabitants now live in cities, and many are somehow connected with the flourishing oil industry and other forms of mineral extraction, not with pastoralism and its foods. The situation in central Asia's other republics is much the same.

The world has thus changed, and with it the ability of small peoples such as the Mongols, or even the far more powerful and influential Kazakhs, to survive by following their herds and living off the products as they have produced them for thousands of years. That way of life and everything associated with it will soon be gone for ever, and with it a fascinating and unique approach to food and food production.

\section{References}

\section{Primary Sources}

Bābur-nāma [Memoirs of Bābur], A. S. Beveridge, translator and editor, two volumes, New Delhi: Oriental Books Reprint Corporation, 1979 [1922].

Divanü Lûgat-it-Türk [Collection of Turkic Dictionaries], compiled by Mahmūd alKāshgarī, Besin Atalay, editor and translator, 3 volumes, Ankara: Türk Tarih kurumu Basimevi, 1985-86.

Herodoti Historiae [Histories of Herodotus], Carolus Hude (ed.), Editio tertia, two volumes, Oxford: Oxford University Press (Oxford Classical Texts), 1927.

The History of the World Conqueror by 'Ala-ad-din 'Ata-Malik Juvaini, J. A. Boyle, translator and editor, two volumes, Manchester: Manchester University Press, 1958.

Huihui yaofang 回回藥方 [Muslim Medicinal Recipes], S. Y. Kong 江潤祥 editor, Hong Kong 香港: Hong Kong Zhong Bianyi Yinwu Youxian Gongsi 香港中編譯印 務有限公司, 1996.

Jujia biyong shilei 居家必用事類 [Various Things for Use at Home], in Shinoda Osamu 筱田統 and Tanaka Seiichi 田内静一, Chūgoku sokukei sōsho 中國食經叢 書, Tōkyō 東京: Shoseki bunbutsu ryūtsūkai 書籍文物流通會, volume 1, 1973.

Mengda beilu 蒙䪈備錄 [Records of the Mongols and Tatar], compiled by Zhao Hong 趙珙, in Wang Guowei 王國維, editor, Menggu shiliao si zhong 蒙古史料四 种, Zhengzhong shuju 正中書局, Taibei 台北, 1962.

Rerum gestarum libri [Books of Things Done], compiled by Ammianus Marcellinus, in J. C. Rolfe (ed.), Loeb edition, three volumes, London: William Heinemann Ltd., 1935-1940.

Secret History of the Mongols, edited by L. Ligeti, Historie Secrète des Mongols, Monumenta Linguae Mongolicae collecta, I, Budaptest: Akadédimai Kiadó, 1971. 
Shuiyun $\ddot{j}$ 水雲集 [Collection on the Water Movement], compiled by Wang Yuanliang 汪元量, Wulin wangzhe yishu 武林往哲速書, 6 , n.d.

Sinica Franciscana, I: Itinera et Relationes Fratrum Minorum saec. XIII et XIV, Anastasius van den Wyngaert editor, Quaracchi-Firenze: College of Santa Bonaventura, 1929.

The Texts and Versions of John de Plano Carpini and William de Rubruquis, C. R. Beazley (ed.), Nendeln, Lichtenstein: Klaus Reprint Limited, 1967 [1903].

Yinshan zhengyao 銀膳正要, compiled by Hu Sihui 忽思惠, edited by P. D. Buell in Buell et al. 2000.

Xivu ji 西遊記, compiled by Li Zhichang 李志常, in Wang Guowei 王國維, ed., Menggu shatiao si zhong 蒙古史料四种, Zhengzhong shuju 正中書局, Taibei 台北, 1962.

Secondary sources

Algar, A. 1991, Classical Turkish Cooking, New York: Harper Collins.

Arsel, S., E. Pekin, and A. Sümer (eds) 1996, Timeless Tastes: Turkish culinary culture, Second Edition, Istanbul: Divan Hotel (Vehbi Koç Vakfi, publication No. 7).

Bat-Ochir, B. 2001, Mongolian Nomadic Society: A reconstruction of the 'Medieval' history of Mongolia, Richmond, Surrey: Curzon.

Buell, P. D. 1994, 'Chinqai (1169-1252): Architect of Mongolian Empire', in E. H. Kaplan, and D. W. Whisenhunt (eds), Opuscula Altaica, Essays Presented in Honor of Henry Schwarz, Center for East Asian Studies (Studies on East Asia, 19), Bellingham, Washington, 168-86.

1999, 'Mongolian Empire and Turkicization: The evidence of food and foodways', In R. Amitai-Preiss (ed.), The Mongol Empire and its Legacy, Amsterdam: E. J. Brill, 200-23.

2003, Historical Dictionary of the Mongol World Empire, Lanham, Md., and Oxford: The Scarecrow Press, Inc. (Historical Dictionaries of Ancient Civilizations and Historical Eras, No. 8).

- 2004, 'Popoli e Ciba della Steppa', in M. Montanari and F. Sabban (eds), Atlante dell'Alimentazione e della Gastronomia, 2 volumes, Torino: UTET, I, 242-57.

- and Ngan Le, 2006, 'Globalization and Mongolia: Blessing or curse?', in H. G. Schwarz (ed.), Mongolia's Culture and Society in Age of Globalization, Bellingham: Center for East Asian Studies, Western Washington University (Studies on East Asia, 26), 27-66.

- E. N. Anderson, and C. Perry 2000, A Soup for the Qan: Chinese dietary medicine of the Mongol era as seen in Hu Szu-hui's Yin-shan Cheng-yao, London: Kegan Paul International (Sir Henry Wellcome Asian Series).

Cahen, C. 1968, Pre-Ottoman Turkey, translated from the French by J. Homes-Williams, London: Sidgwick and Jackson.

Damrinbazar (ed.) 1991 [1987], Mongolyn ideen tovchoo, Ulaanbaatar: BNMAU Shinzhlekh ukhaany khevlel.

Di Cosmo, N. 2002, Ancient China and its Enemies: The rise of nomadic power in East Asian History, Cambridge: Cambridge University Press.

Erdenebaatar, B. 1996, 'Socio-Economic Aspects of the Pastoral Movement Patterns of Mongolian Herders', in C. Humphrey and D. Sneath (eds), Culture and Environment in Inner Asia, two volumes, Cambridge: The White Horse Press, 189-97.

Esin, E. 1980, A History of Pre-Islamic and Early-Islamic Turkish Culture, Istanbul: Unal Matbaası (Supplement to the Handbook of Turkish Culture, Series II, Volume 1/b).

Huang, H. T. 2000. Science and Civilization in China, volume 6, Biology and Biological Technology, part V: Fermentation and Food Science, Cambridge: Cambridge University Press.

Indra, R. 2003, 'Mongolian Dairy Products', in D. Badarch, R. A. Zilinskas, and P. J. Balint (eds), Mongolia Today: Science, culture, environment and development, London: RoutledgeCurson, 69-85.

Ingold, T. 1980, Hunters, Pastoralists and Ranchers, Cambridge: Cambridge University Press (Cambridge Studies in Social Anthropology 28). 
Iwamura Shinobu 岩村忍 1968, Mongoru shakai keizai shi no kenkyū もんごる社会経済 史の研究, Kyōto 京都: Kyodai jinbun kagaku kenkyūjo 巨大人文科學研究所.

Kremenetski, K. 2003, 'Steppe and Forest-steppe Belt of Eurasia: Holocene evironmental history', in M. Levine and C. Renfrew (eds), Prehistoric Steppe Adaptation and the Horse, Cambridge: MacDonald Institute for Archaeological Research, University of Cambridge, 11-27.

Lattimore O. 1962a, 'The Geographical Factor in Mongol History', in O. Lattimore, Studies in Frontier History, Collected Papers 1929-1958, London: Oxford University Press, 241-58.

- 1962b, 'Inner Asian Frontiers: Chinese and Russian Margins of Expansion', in O. Lattimore, Studies in Frontier History, Collected Papers 1929-1958, London: Oxford University Press, 134-59.

Needham, J., Ho Ping-yü and Lu Gwei-djen 1980, Science and Civilization in China, vol. 5: Chemistry and Chemical Technology, part IV: Spagyrical Discovery and Invention: Apparatus, Theories and Gifts, Cambridge, Cambridge University Press.

O'Connell, T., M. Levine and R. Hedges 2003, 'The Importance of Fish in the Diet of Central Eurasian Peoples from the Mesolithic to the Early Iron Age', in M. Levine and C. Renfrew (eds), Prehistoric Steppe Adaptation and the Horse, Cambridge: MacDonald Institute for Archaeological Research, University of Cambridge, 253-68.

Perdue, P. C. 2005, China Marches West, Cambridge, MA, and London: The Belkap Press of Harvard University Press.

Perry, C. 1985, 'A Mongolian Dish', Petits Propos Culinaires 19, 53-5.

_- 2000, 'Grain Foods of the Early Turks', in P. D. Buell, E. N. Anderson, and

C. Perry, $A$ Soup for the Qan: Chinese dietary medicine of the Mongol era as seen in $\mathrm{Hu}$ Szu-hui's Yin-shan Cheng-yao, London: Kegan Paul International (Sir Henry Wellcome Asian Series), 617-38.

— 2001, 'Kitāb al-Tibākha: A fifteenth-century cookbook', in M. Rodinson, A. J. Arberry, and C. Perry, Medieval Arabic Cookery, Blackawton, Totnes, Devon: Prospect Books, 467-75.

Prusek, J. 1971, Chinese Statelets and the Northern Barbarians in the Period 1400-300 B.C., Dordrecht: D. Reidel Publishing Company.

Qatran, D. 2002, Qazaqtyng Dasturli As-Tagham Madenieti (Tarikhi-Etnologiyalyq Zertteu), Almaty, Qazaqtyng Madeniet zhane Onertanu Ghylymi-Zertteu Instituty.

Rinchen, B. 1979, Mongol ard ulsyn ugsaatny sudlal, khelniy shilzleleiyn atlast, 2 volumes, Ulaanbaatar.

Roux, J.-P. 1966, Faune et Flore Sacrées dans les Sociétés Altaiques, Paris: Lbrairie d'Amériques et d'Orient Adrien-Maisonneuve.

- 1984, La religion des Trucs et des Mongols, Paris: Payot.

Scharlipp, W. E. 1992, Die frühen Türken in Zentralasien, eine Einführung in ihre Geschichte und Kultur, Darmstadt: Wissenschaftliche Buchgesellschaft.

Schimmel, A. 1978, The Triumphal Sun: A study of the works of Jalaladdin Rumi, London and the Hague: East-Wind Publications.

Tolybekov, S. Ye. 1971, Kochevoye Obshchestvo Kazakhov v XVII-Nachale XX Veka, Alma-Ata: 'Nauka'.

Tsevel, Ye. 1959, Mongylyn tsagaan idee, Ulaanbaatar: Shinzhlekh ukhaan, deed bolovsrolyn khureellengiyn erdem shinzhilgeeniy khevleliyn gazar (Studia Ethnographica I, 6).

Kumys Shubat 1979, Almaty: Kaynar.

Wang T. and E. N. Anderson 1998, 'Ni Tsan and His "Cloud Forest Hall Collection of Rules for Drinking and Eating"', Petit Propos Culinaires 60, 24-41. 
Von Wissmann, H. 1956, 'On the Role of Nature and Man in Changing the Face of the Dry Belt of Asia', in W. L. Thomas, Jr. (ed.), Man's Role in Changing the Face of the Earth, 2 volumes, Chicago and London: University of Chicago Press, 278-303.

6206 25th Ave., N.E.,

Seattle, Washington, 98115

(206) 528-0257

pbuell@seanet.com 